\title{
PHD Finger Protein 10
}

National Cancer Institute

\section{Source}

National Cancer Institute. PHD Finger Protein 10. NCI Thesaurus. Code C157272.

PHD finger protein 10 (498 aa, $\sim 56 \mathrm{kDa}$ ) is encoded by the human PHF10 gene. This protein is involved in SWI/SNF-mediated chromatin remodeling and promotion of neural progenitor cell proliferation. 